\title{
TRAVEL MOTIVATIONS OF IRANIAN TOURISTS TO TURKEY AND THEIR SATISFACTION LEVEL WITH ALL INCLUSIVE PACKAGE TOURS
}

\begin{abstract}
This study aims to investigate Iranian tourists' travel motivations to Turkey and their satisfaction level with all-inclusive package tours to this country. Based on an indepth literature review, a questionnaire was developed and data was collected from 383 Iranian tourists who stayed in resort hotels in Antalya, Turkey. The research findings reveal that entertainment, being a family friendly destination, weather, cultural resources and quality of resort hotels were the main motivational factors among Iranian tourists for visiting Turkey. Main reasons for the participants for selecting all-inclusive package tours include predetermined schedules, service quality, set price and elimination of extra spending. The research findings show a high level of satisfaction with all-inclusive package tours. However, there were differences among respondents based on gender and age. The study concludes with offering specific theoretical and practical implications. Suggestions for future research are also provided.
\end{abstract}

Key words: All-inclusive package tours, travel motivations, customer satisfaction, service quality, Turkey.

\section{INTRODUCTION}

In many sun, sea and sand destinations, all-inclusive package tours have become a fixture of the vacation industry. These all-inclusive package tours have become a vital component in growing tourists' destinations due to the increased demand in the international market (Ozdemir et al., 2012). The most popular all-inclusive destinations globally are in the Mediterranean and Caribbean countries (Issa and Jayawardena, 2003; Sanliöz Özgen and Kozak, 2015). In line with this trend, since the late 1990s, many resort hotels in Turkey began offering all-inclusive packages (Barak, 2006). Consequently, Turkey has become an international player in the resort hotel industry for the last two decades (Duman and Tanrisevdi, 2011; Gunlu et al., 2010; Sanliöz et al., 2015). According to the Association of Turkish Travel Agencies, Turkey ranked third in selling all-inclusive packages in Europe (TURSAB, 2009). This figure has further increased in recent years. According to TUROFED (2013), the percentage of tourists who travel to Turkey with all-inclusive tour packages is $46 \%$ of the total number of tourists.

Turkey is a popular destination for visitors from different EU and Non-EU countries. Among different countries Russia, Germany, United Kingdom and Iran are the main tourist generators for Turkey. In the latter case, for example, there has been a more than $70 \%$ 
increase in the number of Iranian tourists since visas were abolished between Turkey and Iran in 2010. Since then, Iran has remained one of the main income generators for the Turkish tourism industry (Sharma, 2016). Providing diverse and inexpensive all-inclusive package tours are among the main strategies aimed at attracting an ever growing number of Iranian tourists. Iranians' favourite city destinations include Antalya, Bodrum, Kuşadası and Marmaris, due to their sun, sea and sand products and all-inclusive resorts. Despite such significant developments, no study has so far investigated Iranian tourists' travel motivations and their satisfaction level with all-inclusive holiday package tours to Turkey. Considering Iran's position as one of the main tourist generators for Turkey, this study aims to investigate the main motivational factors among Iranian tourists visiting Turkey and their satisfaction level with all-inclusive holiday packages. The research findings of this study contribute to the existing scholarship by providing specific empirical findings and theoretical discussions regarding the travel motivations of Iranian tourists to Turkey and their satisfaction level with all-inclusive holiday packages.

\section{LITERATURE REVIEW}

\subsection{Destination Choice}

Previous studies have identified factors that influence tourists' destination selection (Gursoy, Chen and Chi, 2014; Jensen and Svendsen, 2016; Nadeau et al., 2008). These factors are classified into pull and push factors (Beerli et al., 2007; Ridderstaat et al., 2014; Uysal and Jurowski 1994; Yoon and Uysal 2005; Rahimi and Akgunduz, 2017). The common push factors are 'escape from everyday environment', 'novelty', 'social interaction', and 'prestige'. On the other hand, pull factors are the features within the destination that attract tourists, such as weather, beaches, mountains or historic and cultural resources. Other studies suggest different types of factors influence tourists' decision making processes for selecting a destination, including tourist characteristics (Papatheodorou, 2001; Zopiatis, Theocharous and Constanti, 2016), destination preferences and awareness (Goodrich, 1978), race (Philipp, 1994), nationality (Pizam and Sussmann, 1995), attitudes (Um and Crompton, 1990).

Ryan and Goodall (1988) classified travel motivations to a destination under four headings: physical (search for relaxation, health, sport), cultural (wish to learn about foreign places), fantasy (escape from the present reality) and social (visits made to friends and relatives or for prestige reasons). Considering specific nationalities and destinations, Kozak 
(1999) found that British tourists visit Turkey for relaxing, enjoying good weather, having fun, forgetting day-to-day problems and increasing knowledge of new places. Tourists from diverse cultural backgrounds also exhibit different behaviour patterns once they have arrived at their destinations, such as trip arrangement, recreation, shopping activities and expenditures (Yuksel, 2004).

\subsection{All-Inclusive Package Tours}

Basala and Klenosky (2001) describe the all-inclusive tourist as a visitor who prefers to experience the host community through the protection of "environmental bubble" that allows $\mathrm{him} /$ her to interact and function at a familiar level of comfort and security hence they can be considered as organized mass tourist suggested by Cohen (1972). All-inclusive package tours are normally standardized, quality-controlled and repeatable offers comprising two or more elements of transportation, accommodation, food, entertainment, destination attractions, and other facilities and services (such as travel insurance), which are sold to tourists as a package for a single price (Alegre and Sard, 2015; Chang et al., 2007; Middleton, 1994; Sheldon and Mak, 1987; Koc, 2016; Wang et al., 2016).

There are various types of all-inclusive package tours offered in the tourism industry (Lo and Lam, 2004). The main differences are the types of services they offer to the guests. Ultra all inclusive (UI) system includes accommodation, breakfast, lunch and dinner (domestic and foreign, hot and cold), alcohol free drinks and a variety of activities are free in it. Mega all inclusive (MI) system includes accommodation, breakfast, lunch and dinner with domestic and foreign alcoholic drinks during the day, hot-cold, soft drinks, all kinds of food and all activities. Mega ultra (Imperial) all inclusive (MUI) system offers accommodation, breakfast, lunch and dinner, domestic and foreign alcoholic drinks day long, hot-cold soft drinks, all kinds of food, all activities in the facilities and also tour done outside of hotel are included in the price (Gürkan, 2002; Heung and Chu, 2000; Wong and Kwong, 2004). According to the study conducted by Üner et al. (2007) majority of the four and five star accommodation businesses applied classic and ultra-all-inclusive system. However some of the previous studies suggested that resort hotels employing all-inclusive system in Turkey are likely to reduce their service quality level to increase their profitability (Koc, 2005; Çiftçi et al., 2007; Üngüren and Cengiz, 2009, Yayla and Yayl1, 2012). 


\subsection{Travellers Motivations for Using All-Inclusive Package}

Previous studies have identified different motivational factors, from the customers' point of view, for selecting all-inclusive package tours. These studies suggest that the most important selection criteria include economic reasons (Alegre and Sard, 2015; Issa and Jayawardena, 2003; Sülküm, 2006) and overall convenience (Heung and Chu, 2000), elimination of unexpected costs/expenses (Issa and Jayawardena, 2003), personal safety , standardized itenary, quality controlled and repeatable offer (Issa and Jayawardena, 2003; Sülküm, 2006), a guaranteed departure date, promised consistency (Lo and Lam, 2004) and eliminated surprises, the travel agency's reputation (Heung and Chu, 2000), word-of-mouth communication, and staff attitude (Wong and Kwong, 2004). These findings further suggest that package tours offer travellers more convenience and value, a reduced possibility of hassles and surprises, an increased sense of security and safety, the social benefits of traveling with a group of people, and the convenience of being escorted throughout the trip (Alegre and Sard, 2015; Sülküm, 2006; Wong and Kwong, 2004). Overall, given their well-organized nature, all-inclusive package tours can save travellers time and money, provide safety, new social contacts, reliable transportation, and a wide range of sports and entertainment (Anderson et al., 2009; Heung and Chu, 2000). All-inclusive packages can also allow tourists to plan more effectively since they can better predict their overall costs for experiences and goods. For example, tourists can determine which resort hotel is the most appropriate for them and what features are offered (Anderson, 2008; Issa and Jayawardena, 2003).

Studies on tourists' choice of package tours have shown that the reasons for choosing the type of package are the offered itinerary, price, friends' recommendations, and the convenience of the departure dates (Alegre and Sard, 2015; Wong and Lau, 2001). In addition to travel product preferences, travel-related behaviours play a significant role in selection of package tours. For example Quiroga (1990) stated that the necessities and interests of people who travel alone are different from those who travel with relatives or friends. Kanellopoulos (2008) claims that in the group package tour decision-making process, tourists take various factors into consideration while planning a group package tour, such as the kind of group package tour, destination country, departure date, accommodation and food quality, optional activities, cost and length of tour, activities (sport and non-sport activities), travel risk, travel agency and tour guide.

Package tour travellers are often accompanied by their spouses, family members or friends (Pearce, 1982; Wu et al., 2014). People who travel with their family members place more emphasis on facilities and safety, and accessibility factors than those who are traveling 
alone (Lai and Graefe, 2000). First time travellers tend to prefer package tours more than seasoned travellers (Andereck and Caldwell, 1993; Lai and Graefe, 2000; Yuksel, 2004). According to Fesenmaier et al. (2003), tourists' choices can be classified into two broad categories: personal and travel characteristics. Personal characteristics encompass socioeconomic status and demographic factors. Indicators of socio-economic status are education and occupation. Other predictors of the dependent variables are demographic characteristics, such as age and gender, which this study relates to tourist preferences of all-inclusive systems.

It can be concluded that factors such as economic reasons and overall convenience, elimination of unexpected costs, personal safety, standardized, quality controlled and repeatable offer, a guaranteed departure date, promised consistency and eliminated surprises; travel agency's reputation, word-of-mouth communication, and staff attitude are the key players for selecting all-inclusive package tours (Chang et al., 2007; King et al., 2004; Lai and Graefe, 2000; Pearce, 1982; Wu et al., 2014). Also package tours offer travellers more convenience and value, a reduced possibility of hassles and surprises, an increased sense of security and safety, social benefits of traveling with a group of people, and the convenience of being escorted throughout the trip.

\subsection{Satisfaction Level of Travellers with All-Inclusive Travel Packages}

Customer satisfaction literature is dominated by measurement of guest satisfaction with tourism and hospitality services (Bowen and Chen-McCain, 2015; Kozak, 2001; Oh and Kim, 2017; Pizam, Shapoval and Ellis, 2016; Rahimi and Kozak, 2017). Service quality and customer satisfaction has a direct impact on retention and loyalty to a specific tourist product or destination (Hemsley-Brown and Alnawas, 2016; Kandampully, Zhang, and Bilgihan, 2015; Rahimi, 2017; Rahimi and Gunlu, 2016; Rauch et. al., 2015; Yolal, Chi and Pesämaa, 2017). Previous studies found different key factors for travellers' satisfaction with allinclusive packages (Lo and Lam, 2004; Ozdemir et al., 2012; Yolal et al., 2017). Lo and Lam (2004) in their study found personal safety as one of the important factors. Ozdemir et al. (2012) found that quality of accommodation, variety of food and beverages, quality of food and beverages, cleanliness and hygiene, price, staff attitude and the quality of recreational activities are the important factors for customer satisfaction in all-inclusive packages. Looking at the impact of demographic factors on satisfaction, gender is likely to influence tourists' satisfaction because female tourists have more realistic expectations given their taskoriented attitude toward holidays. Women and men have different holiday involvement 
(Deem, 1996), participation patterns and commitment to various holiday activities (Wiley et al., 2000). One can also assume that female tourists may be more satisfied with all-inclusive package tours since they do not need to worry about preparing and serving food to their family members during their travels (Heung and Chu, 2000; Heung et al., 2001). On the other hand, King et al. (2004) found that tourists who chose package tours are particularly dissatisfied with certain features, especially those including excessive time allocated to shopping, unappealing tour itineraries, lack of provisions for visiting or experiencing interesting attractions, an absence of choice over shopping venues, and poor accommodation quality.

\section{METHODOLOGY}

A quantitative research methodology was adapted for the current study. A questionnaire was developed based on an in-depth literature review, which had three sections. The first section included demographic questions (e.g. gender, age, education and number of children). The second section included questions related to travel behaviours, such as frequency of travel, choice of destination, themes of interest, tour information, reasons for travelling, the activities offered outside the hotel during the holiday, and how tourists learned about the all-inclusive system. The questions in this section were developed based on several previous studies (Alcaniz et al., 2009; Assaker et al., 2011; Beerli and Mart1'n, 2004; Kanellopoulos, 2008). The third section included questions related to the selection criteria for all-inclusive packages and tourists' satisfaction level with them. The items in the second and third sections in the questionnaires were developed from several previous studies (Anderson, 2008; Assaker et al., 2011; Callan and Bowman, 2000; Heung and Chu, 2000; Middleton, 1991; Quiroga, 1990; Sheldon and Mark, 1987; Wong and Kwong, 2004; Wang et al., 2007; Kanellopoulos, 2008). The questionnaire items were on a 5-point Likert-type scale, ranging from 1 (strongly disagree) to 5 (strongly agree).

The questionnaire was first developed in Turkish and translated into Persian by one of the authors who is fluent in both Persian and Turkish. Checking for consistency, an expert then translated the questionnaire back to Turkish. Finally, a professional translator then crosschecked all three versions of the questionnaire to ensure precision and uniformity. A pilot test was undertaken with 50 Iranian tourists who purchased all-inclusive packages, and subsequent edits and changes were made to the survey. The sample group included Iranian tourists who purchased ultra-all-inclusive package tours and stayed in the Lara and Kundu regions in Antalya, Turkey. Antalya was selected for its unique popularity among Iranian 
tourists. The survey was conducted after check-out, and the data was collected from 10 five star hotels. The questionnaire was distributed by one of the authors to 650 Iranian tourists and 390 completed questionnaires were returned. After an initial analysis, it was noted that seven questionnaires were incomplete, and they were eliminated from the analysis. With the response rate of $58.9 \%$ in total, 383 questionnaires were used for the statistical analysis.

Scale reliability was measured by calculation of Cronbach's alpha $(\alpha)$ coefficient. Accordingly, the reliability coefficient of the questionnaire was established as 0.98 , which was above the rate suggested by Hair (2015). Data was analysed with univariate descriptive statistics, including frequencies and mean ratings and t-test. The main motivation factors and perceptions of all-inclusive system satisfaction attributes were first analysed with frequencies and mean scores. Finally, independent sample t-tests were adapted to test whether the mean scores of the underlying dimensions of all-inclusive satisfaction attributes differed significantly according to the demographic profile (gender, age, education and number of children) of the respondents.

\section{RESULTS}

Table 1 presents the demographic information of the participants. The gender distribution of respondents was $44.9 \%$ female and $55.1 \%$ male. Given the male dominated society in Iran (Hofstede, 1980); it is possible that male respondents might have volunteered more frequently than females to fill out the questionnaire. The three dominant age groups of the respondents were 20-29 (30.4\%), 30-39 (26.3\%) and 40-49 (16.5\%), whereas the age group 50-59 (10.5\%) and senior travellers aged 60 years and older made up the smallest group. In terms of level of education, $31 \%$ of the respondents had high school qualification, $31.3 \%$ college or university, and $14.2 \%$ postgraduate degrees. In addition, about $53.4 \%$ of participants were families with children. 
Table 1 Description of the respondents $(n=383)$

\begin{tabular}{|c|c|c|}
\hline & N & $\%$ \\
\hline Gender & & \\
\hline Male & 211 & 55.1 \\
\hline Female & 172 & 44.9 \\
\hline Education & & \\
\hline Elementary & & \\
\hline Secondary & 28 & 7.3 \\
\hline High School & 61 & 16.1 \\
\hline Undergraduate & 118 & 31.1 \\
\hline Postgraduate & 54 & 31.3 \\
\hline Age & 119 & 14.2 \\
\hline 18 to 19 & & \\
\hline 20 to 29 & 45 & 11.8 \\
\hline 30 to 39 & 116 & 30.4 \\
\hline 40 to 49 & 100 & 26.3 \\
\hline 50 to 59 & 63 & 16.5 \\
\hline 60 or older & 40 & 10.5 \\
\hline Number of children & 17 & 4.5 \\
\hline No Child & & \\
\hline 1 & 178 & 46.6 \\
\hline 2 & 81 & 21.2 \\
\hline 3 & 89 & 23.3 \\
\hline More than 4 & 5 & 7.6 \\
\hline
\end{tabular}

As presented in Table 2, in terms of motivating factors for visiting Turkey, $57.2 \%$ of the respondents indicated that entertainment and relaxation was their first reason. This was then followed by Turkey being a family destination $(41.5 \%)$, good climate $(34.2 \%)$ and having cultural resources $(30.2 \%)$. The research findings further indicate that the participants chose Turkey not just for one reason but a combination of different reasons, including entertainment, relaxation, rich culture and good climate. The availability of all-inclusive packages ranked the sixth most important factor for selecting Turkey. This suggests that the participants did not choose Turkey solely for the prevalence of all-inclusive package tours. 
Table 2 Respondents' reasons for preferring Turkey as their holiday destination $(n=383)$

\begin{tabular}{lcc}
\hline & $\mathrm{N}$ & $\%$ \\
\hline Entertainment \& relaxation & 219 & 57.2 \\
Family destination & 159 & 41.5 \\
Good climate & 131 & 34.2 \\
Cultural resources & 117 & 30.5 \\
Quality hotels & 67 & 17.5 \\
All-inclusive system & 58 & 15.1 \\
Sea & 51 & 13.3 \\
Price & 36 & 9.4 \\
Rich cuisine & 32 & 8.4 \\
Sympathetic people & 28 & 7.3 \\
Adventure & 22 & 5.8 \\
Safety & 19 & 5.0 \\
Business & 17 & 4.4 \\
Historical richness & 14 & 3.7 \\
Health & 3 & 0.8 \\
\hline
\end{tabular}

*The respondents could select multiple items

Table 3 presents the results concerning the activities in which tourists participated. About $91.1 \%$ of the respondents participated in activities outside their resort hotels. Shopping was the most important activity undertaken by $72 \%$ of the participants followed by their participation in nature tours. Each participant claimed to have spent about 2000 Euros on these activities.

Table 3 Respondents' participation in activities were outside the hotels applied all-inclusive system during their holiday $(\mathrm{n}=383)$

\begin{tabular}{lcc}
\hline & N & $\%$ \\
\hline Shopping & 275 & 71.8 \\
Nature tours & 162 & 42.3 \\
Leisure tours & 119 & 31.1 \\
Tours to historical places & 110 & 28.7 \\
Sports activities & 57 & 14.9 \\
didn't participate in any activities & 34 & 8.9 \\
\hline
\end{tabular}

The respondents could select multiple items

Table 4 presents the main reasons for choosing the all-inclusive system. According to the findings of this study, the participants preferred all-inclusive package tours because such tours offered an established vacation plan (39.8\%), the elimination of extra spending (31.4\%) and quality service (29.6\%). Other main reasons include value for money and no obligation to closely monitor spending. 
Table 4 The key reasons for preferring allinclusive system $(\mathrm{n}=383)$

\begin{tabular}{lcc}
\hline & $\mathrm{N}$ & \%* \\
\hline Vacation plan is ready & 152 & 39.8 \\
Elimination of extra spending & 120 & 31.4 \\
Quality service & 113 & 29.6 \\
Convenient price & 81 & 21.2 \\
No obligation to monitor spending & 73 & 19.1 \\
\hline Do not need to carry more money & 57 & 14.9 \\
Having the longer-term vacation & 42 & 11.0 \\
\hline *Respondents could choose & &
\end{tabular}

Table 5 presents the research findings related to the respondents' satisfaction level with all-inclusive package tours. Overall, the respondents were satisfied with the quality of services and products offered within the all-inclusive system (mean=3.57). Safety of guests, cleanliness of rooms, healthy and hygienic products and services received higher satisfaction mean scores than other statements. The respondents' satisfaction with service quality was shown statistically significant in terms of gender and age. As shown in Table 6, the mean score for female tourists was higher than the mean score for male tourists. Respondents' age appears to have affected how they perceive service quality in the all-inclusive system. Differences in the age group variables were caused by the high average of the over 50 age group (mean=3.90) and also the mean of the 30-39 age group variable in service quality satisfaction, and the mean of the 20-29 age group variable (mean=3.37) in getting value for money satisfaction was determined to be low. The participants who were older than 50 years were more satisfied with the service quality of the all-inclusive system than younger tourists.

\section{Insert Table 5 here please \\ Insert Table 6 here please}

\section{CONCLUSIONS AND IMPLICATIONS}

\subsection{Conclusions}

This study aimed to investigate the main motivational factors among Iranian tourists for visiting Turkey and their satisfaction level with all-inclusive holiday packages. This is one 
of the very few research studies focusing on the criteria used by Iranian tourists in selecting all-inclusive package tours when visiting Turkey. The findings offer new insights on what Iranian tourists may consider important when choosing a destination and purchasing allinclusive package tours. Several conclusions can be drawn from the data presented above. The study findings reveal that entertainment facilities, a family-friendly environment, good climate and quality of accommodations are the main motivational factors for them when deciding to visit Turkey. They also reveal that the participants did not choose Turkey for its availability of all-inclusive package tours. Based on this, it can be claimed that all-inclusive package tours are a mechanism to offer tourists access to entertainment, relaxation, good climate, quality accommodations and food. The main reasons for selecting all-inclusive packages include predetermined schedules, set prices, the elimination of extra spending and quality of service. The research findings show a high level of satisfaction with all-inclusive package tours. However, there were differences among the tourists based on gender and age. The research findings offer specific theoretical and managerial implications, which are provided below.

\subsection{Theoretical Implications}

Tourists from diverse cultural backgrounds may exhibit different behaviour patterns in trip arrangement, recreation, shopping and spending. For example, Kozak (1999) found that British tourists chose Turkey as their destination for relaxing, enjoying good weather, having fun, forgetting day-to-day problems and increasing knowledge of new places. However, our study findings suggest that Iranian tourists choose Turkey for reasons other than sun, sea and sand, including entertainment, culture and cuisine. Based on this finding, it can be assumed that tourists from the Middle East and Asia may choose Turkey for cultural tourism, entertainment and cuisine.

Several previous studies noted that shopping is often one of the main appeals of visiting a tourist destination and is among the most pervasive of tourist activities (Turner and Reisinger, 2001; Timothy and Butler, 1995). Yet, earlier research on all-inclusive package tours (Barak, 2006; Sülküm, 2006; Anderson, 2008; Üngüren and Cengiz, 2009) suggests that tourists who chose them do not generally spend much time outside their hotels, and therefore do not devote much of their budget to shopping. The study findings of this current study do not support this claim since it was found that a very high percentage of the Iranian tourists who participated in this study went out from their resort hotels to experience outside activities, including shopping, nature, leisure and historical tours. It is possible that tourists 
who choose all-inclusive packages may spend less money on food and drinks outside their resorts, but they seem to participate in shopping and attend local nature and historical tours.

The participants seem to prefer all-inclusive package tours because such tours offer an established vacation plan, the possible elimination of extra spending and quality service. These findings are consistent with previous research studies in this area, and lend new empirical data to support these claims (Anderson, 2008; Çifçi et al., 2007; Demir, 2002; Heung and Chu, 2000; Yaylı and Yayla, 2012). Previous studies suggest that resort hotels offering all-inclusive package tours in Turkey are likely to reduce the level of service quality to increase their profitability (Koc, 2005; Çiftçi et al., 2007; Üngüren and Cengiz, 2009, Yayla and Yayl1, 2012). However, the current study found that the respondents who participated in this study were highly satisfied with the quality of service they received with an all-inclusive system. It would be interesting to compare the satisfaction levels of tourists from different countries choosing all-inclusive package tours to visit different destinations, such as Turkey, Greece and Egypt.

Looking at the demographic factors, the study findings show that female tourists are more satisfied with the service quality of all-inclusive systems and thus are more likely to rate this dimension higher than their male counterparts. Gender is therefore likely to influence tourists' satisfaction because female tourists have more realistic expectations given their taskoriented attitudes about holidays. Women and men have different holiday involvement (Deem, 1996), participation patterns and commitment to various holiday activities (Wiley et al., 2000).

According to the study findings, Iranian tourists who were older than 50 years were more satisfied with the service quality of an all-inclusive system than younger tourists. The research findings of this study further indicate that participants were well-educated, generally young couples in the $20 \mathrm{~s}$ and 30 s age group. The results also show that education and the number of children seem to have a different effect on satisfaction with service quality and getting their value for the money with all-inclusive package tours in comparison with gender and age factors. These findings suggest that nationality and demographic features may impact tourists' levels of satisfaction with all-inclusive package tours.

Previous studies put much emphasis on the evolving role of females in the travel decision-making process (Litvin, $\mathrm{Xu}$ and Kang, 2004; Josiam et al., 2005). This is perhaps the case in Western countries. Results from this current study suggest that male tourists who preferred an all-inclusive system seem to be as influential as females in choosing all-inclusive package tours. The study findings also indicate that although the natural and cultural 
attractions of Turkey are of high importance for international tourists, they are of little importance for Iranian tourists.

\subsection{Practical Implications}

The research findings suggest that tourists choose Turkey for several reasons, and that the availability of all-inclusive tour packages does not appear to be the most important factor. However, it is seen as a mechanism to bundle important features for a safe, economical, and enjoyable family holiday. Tourists choose Turkey for sun, sea, sand, and other factors, depending on their country of origin. They also visit Turkey for entertainment, climate, culture, quality hotels and cuisine (Okumus et al., 2012). The tourism industry in Turkey should therefore diversify their products and services and alter their marketing strategies, beyond those that celebrate the prevalence of sun, sea and sand.

The existence of an open social environment, one that offers concerts and beach tourism, provides ample attractions for Iranian tourists. The geographical position of Turkey, its closeness to Iran, and the lack of visa requirements are also among the important factors that compel many Iranian tourists to choose a holiday in Turkey. The recreational attractions and shopping opportunities are of high importance for tourists visiting Turkey. Some of the other Turkish pull factors for Iranian tourists include the quality of the services and hospitality infrastructure available, and several religious, cultural and linguistic similarities.

The study findings suggest that a very high percentage of the respondents participated in outside activities including shopping and local tours and they spent a considerable amount of money outside their resort hotels. This is indeed an interesting finding for local businesses and such tours, and it suggests that shopping opportunities should be highlighted in marketing efforts for all-inclusive package tours. In addition, future studies may compare tourists from different countries in terms of their participation in outside activities. The research findings indicate that knowing all the details of the activities and programs of all-inclusive package tours is important for Iranian tourists in their selection of all-inclusive package tours. Additionally, the participants were well-educated and generally young couples in the 20s and 30s age group. Thus, all-inclusive packages for Iranian tourists and those from similar countries should cater particularly to this segment's needs and expectations. Historically, many all-inclusive resort hotels in Turkey target tourists from Europe and Russia. This may mean that all-inclusive package tours to Turkey for Iranian tourists need to be tailored and modified to meet the needs and expectations of tourists from this country. 
Iranian tourists who participated in this current study were satisfied with the service quality of all-inclusive package tours. A statistically significant relation was found between respondents' satisfaction from all-inclusive system and the service quality variables. It was determined that resort hotels offering all-inclusive systems could meet the service quality expectations of the respondents. Having said this, one of the main issues of all-inclusive systems in Turkey has been the lack of supervision and close inspection of resorts in terms of standards, service quality, hygiene and other areas. Such quality control efforts can ensure and improve the service quality standards of all-inclusive holiday packages to Turkey.

\subsection{Limitations and Future Research}

Several limitations in this study provide avenues for further research. While this study collected data from Iranian tourists visiting Antalya, Turkey, future studies can collect data from tourists originating from different countries and staying at all-inclusive resorts in different cities in Turkey. Future research can also focus on longitudinal approaches in measuring costumers' satisfaction and the relationship between satisfaction and activities offered during all-inclusive package tours. More research is also needed to consider satisfaction levels among tourists who do not choose all-inclusive packages, particularly their satisfaction with hotel and food quality, safety and hygiene, as well as the reasons why they choose Turkey as their holiday destination. Finally, the satisfaction level with all-inclusive packages among first time and repeat customers is also an area worthy of further investigation.

\section{REFERENCES}

Alegre, J., \& Sard, M. (2015). When demand drops and prices rise. Tourist packages in the Balearic Islands during the economic crisis. Tourism Management, 46, 375-385.

Alegre, J., \& Sard, M. (2015). When demand drops and prices rise. Tourist packages in the Balearic Islands during the economic crisis. Tourism Management, 46, 375-385.

Andereck, K. L., \& Caldwell, L. L. (1993). The Influence of Tourists' Characteristics on Ratings of Information Sources for an Attraction. Journal of Travel and Tourism Marketing, 2 (2/3): 171-89.

Anderson, W. (2008). Analysis of All-inclusive travel mode: demand and supply perspectives In the Balearic Islands. Doctoral Thesis. University of Balearic Islands. Department of Applied Economics.

Anderson, W., Juaneda, C., \& Sastre, F. (2009). Influences of pro- all-inclusive travel decisions. Tourism Review, 64(2), 4-18.

Asadi, R. \& Daryaei, M. (2011). Prioritization of Pull Factors of China as a Destination for Iranian Tourists. Australian Journal of Basic and Applied Sciences, 5(11): 1129-1135. 
Assaker G, V. VE. \& Connor, PO. (2011) Examining the effect of novelty seeking, satisfaction, and destination image on tourists' return pattern: a two factor, non-linear latent growth model. Tourism Management 32: 890-901.

Barak, H. (2006). Turizm Sektöründe Uygulanan Herşey Dahil Tatil Sisteminin Bölgedeki İşletmelerde Üzerindeki Etkisi ve Bodrum Örneği. Yayınlanmış Yüksek Lisans Tezi, Dokuz Eylül Üniversitesi Sosyal Bilimler Enstitüe, Turizm İşletmeciliği Anabilim Dalı, İzmir.

Basala, S. \& Klenosky, D. (2001). Travel Style Preferences for Visiting a Novel Destination: A Conjoint Investigation Across the Novelty-Familiarity Continuum, Journal of Travel Research, 40 (2), 172-182.

Beerli, A., Meneses, G. D., \& Gil, S. M. (2007). Self-congruity and destination choice. Annals of Tourism Research, 34(3), 571-587.

Bowen, J. T., \& Chen McCain, S. L. (2015). Transitioning loyalty programs: A commentary on "the relationship between customer loyalty and customer satisfaction". International Journal of Contemporary Hospitality Management, 27(3), 415-430.

Callan, R.J., \& Bowman, L. (2000). Selecting a Hotel and Determining Salient Quality Attributes: A Preliminary Study of Mature British Travellers. International Journal of Tourism Research, 2(2): 97-118.

Chang J, Wang KC, Guo YZ, Su CJ, \& Yen SJ. (2007).Trends in outbound group package tours in China and Taiwan: a marketing mix perspective. Tourism Analysis, 12(4): 257-70.

Çifçi, H., Düzakın, E. \& Önal, Y.B. (2007). All Inclusive System and Effects on the Turkish Tourism Sector, Problems and Perspectives in Management, 5(3): 269- 275

Deem, R. (1996) Women, the City and Holidays, Leisure Studies 15: 105-19.

Demir, F.Ö. (2002). Turizm İşletmelerinde Herşey Dahil Fiyat Sisteminin Maliyet ve Karlılık Üzerine Etkisinin Analizi, Yayınlanmamış Yüksek Lisans Tezi, Akdeniz Üniversitesi Sosyal Bilimler Enstitüsü, Antalya.

Duman, T., \& Tanrisevdi, A. (2011). Profiling of English tourists visiting Turkey based on attitudes toward Internet use in vacation decision making. Journal of Hospitality Marketing \& Management, 20(5), 525-550.

Fesenmaier D., Ricci, F., Schaumlechner, E., Wöber, K. \& Zanella, C. (2003). Dietorecs: Travel Advisory for Multiple Decision Styles. In Proceedings of the ENTER 2003 Conference, pp: 232-242, Helsinki, Finland.

Ganesan-Lim, C., Russell-Bennett, R., \& Dagger, T. (2008). The impact of service contact type and demographic characteristics on service quality perceptions. Journal of Services Marketing, 22(7), 550-561.

Goodrich, J. N. (1978). The relationship between preferences for and perceptions of vacation destinations: Application of a choice model. Journal of Travel research, 17(2), 8-13.

Güneş, A. (2003). Turizmde "Herşey Dahil” Karmaşas1, http://www.guneyege.net. Accessed: 08.06.2010.

Gunlu, E., Aksarayli, M., \& Sahin Perçin, N. (2010). Job satisfaction and organizational commitment of hotel managers in Turkey. International Journal of Contemporary Hospitality Management, 22(5), 693-717.

Gürkan, T. A. (2002). "Herşey Dahil" (All Inclusive) Sistemin Türk Turizmi Açısından İncelenmesi (Antalya-Kemer Örneği). Yayınlanmış Yüksek Lisans Tezi, Sakarya Üniversitesi. Sosyal Bilimler Enstitüsü, İşletme Anabilim Dalı, Turizm İşletmeciliği Bilim Dalı, Sakarya.

Gursoy, D., S. Chen, J., \& G. Chi, C. (2014). Theoretical examination of destination loyalty formation. International Journal of Contemporary Hospitality Management, 26(5), 809-827. 
Hair, J. F. (2015). Essentials of business research methods. ME Sharpe.

Hemsley-Brown, J., \& Alnawas, I. (2016). Service quality and brand loyalty: the mediation effect of brand passion, brand affection and self-brand connection. International Journal of Contemporary Hospitality Management, 28(12). pp.2771-2794,

Heung, V. C., \& Chu, R. (2000). Important factors affecting Hong Kong consumers' choice of a travel agency for all-inclusive package tours. Journal of travel research, 39(1), 52-59.

Hsu, T. K., Tsai, Y. F., \& Wu, H. H. (2009). The preference analysis for tourist choice of destination: A case study of Taiwan. Tourism Management, 30(2), 288-297.

Issa, J. J., \& Jayawardena, C. (2003). The "all-inclusive" concept in the Caribbean. International Journal of Contemporary Hospitality Management, 15(3), 167-171.

Jensen, S., \& Svendsen, G. T. (2016). Social Trust, Safety and the Choice of Tourist Destination. Business and Management Horizons, 4(1), 1.

Josiam, B. M., Kinley, T. R. \& Kim, Youn-Kyung. (2005). Involvement and The Tourist Shopper: Using The Involvement Construct To Segment The American Tourist Shopper At The Mall. Journal of Vacation Marketing, 11(2), 135-154.

Kanellopoulos, D. N. (2008). An ontology-based system for intelligent matching of travellers' needs for Group Package Tours. International Journal of Digital Culture and Electronic Tourism, 1(1), 76-99.

Koc, E. (2005). The role of family members in the family holiday purchase decisionmaking process. International Journal of Hospitality \& Tourism Administration, 5(2), 85102.

Koc, E. (2016). Food Consumption in All-inclusive Holidays: Illusion of Control as an Antecedent of Inversionary Consumption. Journal of Gastronomy and Tourism, 2(2), 107-116.

Kozak, M., \& Rimmington, M. (2000). Tourist satisfaction with Mallorca, Spain, as an offseason holiday destination. Journal of travel research, 38(3), 260-269.

Kozak, M., (1999). Destination Competitiveness Measurement: Analysis of Effective Factors and Indicators. Tourism Management. 23(3): 221-223.

Kozak, M., (2001). Comparative assessment of tourist satisfactions with destinations across two nationalities. Tourism Management 22: 391-401.

Kandampully, J., Zhang, T., \& Bilgihan, A. (2015). Customer loyalty: a review and future directions with a special focus on the hospitality industry. International Journal of Contemporary Hospitality Management, 27(3), 379-414.

Lai, L.H. \& Graefe, A. R. (2000). Identifying Market Potential and Destination Choice Factors of Taiwanese Overseas Travelers. Journal of Hospitality \& Leisure Marketing 6(4): 45-65.

Litvin, S. W., Xu, G., \& Kang, S. K. (2004). Spousal Vacation Buying Decision Making Revisited Across Time and Place. Journal of Travel Research, 43(2), 193-198.

Lo, A., \& Lam, T. (2004). Long-haul and short-haul outbound all-inclusive package tours. Asia Pacific Journal of Tourism Research, 9(2), 161-176.

Middleton, V.T.C. (1991). Whither the Package Tour? Tourism Management, 12(3): 185192.

Middleton, V.T.C. (1994). Marketing in Travel and Tourism, Oxford: ButterworthHeinemann.

Nadeau, J., Heslop, L., O'Reilly, N., \& Luk, P. (2008). Destination in a country image context. Annals of tourism Research, 35(1), 84-106.

Oh, H. and \& Kim, K. (2017). Customer satisfaction, service quality, and customer value: years 2000-2015. International Journal of Contemporary Hospitality Management, 29(1), 2-29. 
Okumus, F., Avci, U., Kilic, I., \& Walls, A. R. (2012). Cultural tourism in Turkey: A missed opportunity. Journal of Hospitality Marketing \& Management, 21(6), 638-658.

Ozdemir, B., Çizel, B., \& Bato Cizel, R. (2012). Satisfaction with all-inclusive tourism resorts: The effects of satisfaction with destination and destination loyalty. International Journal of Hospitality \& Tourism Administration, 13(2), 109-130.

Papatheodorou, A. (2001). Why people travel to different places. Annals of tourism research, 28(1), 164-179.

Pearce, P. (1982). The Social Psychology of Tourist Behavior, New York: Pergamon Press.

Philipp, S. F. (1994). Race and tourism choice: a legacy of discrimination?. Annals of Tourism Research, 21(3), 479-488.

Pizam, A., Pizam, A., Shapoval, V., Shapoval, V., Ellis, T., \& Ellis, T. (2016). Customer satisfaction and its measurement in hospitality enterprises: a revisit and update. International Journal of Contemporary Hospitality Management, 28(1), 2-35.

Pizam, A., \& Sussmann, S. (1995). Does nationality affect tourist behavior?. Annals of Tourism Research, 22(4), 901-917.

Qu, H., \& Li, I. (1997). The Characteristics and Satisfaction of Mainland: Chinese Visitors To Hong Kong. Journal of Travel Research, Spring, 37-41.

Quiroga, I. (1990). Characteristics of Package Tours in Europe. Annals of Tourism Research. 17(2): 185-207.

Rahimi, R \& Akgunduz, Y.( 2017). Driving Force Analysis of East European Students to Study Tourism and Hospitality in the UK. Anatoli, An International Journal of Tourism and Hospitality Research. DOI: 10.1080/13032917.2017.1311273.

Rahimi, R., \& Kozak, M. (2017). Impact of Customer Relationship Management on Customer Satisfaction: The Case of a Budget Hotel Chain. Journal of Travel \& Tourism Marketing, 34(1), 40-51.

Rahimi, R. (2017) Customer Relationship Management (People, Process and Technology) and Organisational Culture in Hotels: Which traits matter?. International Journal of Contemporary Hospitality Management. 29 (5) . DOI: 10.1108/IJCHM-10-20150617.

Rahimi, R., \& Gunlu, E. (2016). Implementing Customer Relationship Management (CRM) in hotel industry from organisational culture perspective. International Journal of Contemporary Hospitality Management. 28 (1). 89 - 112.

Ridderstaat, J., Oduber, M., Croes, R., Nijkamp, P., \& Martens, P. (2014). Impacts of seasonal patterns of climate on recurrent fluctuations in tourism demand: Evidence from Aruba. Tourism Management, 41, 245-256.

Rauch, D. A., Collins, M. D., Nale, R. D., \& Barr, P. B. (2015). Measuring service quality in mid-scale hotels. International Journal of Contemporary Hospitality Management, 27(1), 87-106.

Ryan, C., \& Glendon, I. (1998). Application of Leisure Motivation Scale to Tourism. Annals of Tourism Research, 25(1): 169-184.

Sanliöz Özgen, H. K., \& Kozak, M. (2015). Social media practices applied by city hotels: a comparative case study from Turkey. Worldwide Hospitality and Tourism Themes, 7(3), 229-241.

Sharma, S. (2016). Turkish hoteliers stare into abyss as tourism industry reels. [online] Middle East Eye. Available at: http://www.middleeasteye.net/news/turkish-hoteliersstare-abyss-tourism-industry-reels-497110305 [Accessed 13 Dec. 2016].

Sheldon, P. J., \& Mak, J. (1987). The demand for package tours: A mode choice model. Journal of Travel Research, 25(3), 13-17.

Sülküm, N. (2006). Türkiye'de Hizmet Sektöründeki Turizm İşletmelerinde Uygulanan "Herşey Dahil” Sisteminin Müşteri Memnuniyeti Üzerindeki Etkisinin Ölçümlenmesi 
ve Bir Alan Araştırması. Yayınlanmış Yüksek Lisans Tezi, Adnan Menderes Üniversitesi Sosyal Bilimler Enstitüsü, Aydın.

Taylan Dortyol, I., Varinli, I., \& Kitapci, O. (2014). How do international tourists perceive hotel quality? An exploratory study of service quality in Antalya tourism region. International Journal of Contemporary Hospitality Management, 26(3), 470-495.

Timothy, DJ. \& Butler, RW. (1995). Cross-border shopping: a North American perspective. Annals of Tourism Research. 22(1): 16-34.

Tsiotsou, R. \& Vasioti, E. (2006). Using Demographics and Leisure Activities to Predict Satisfaction with Tourism Services in Greece. Journal of Hospitality \& Leisure Marketing, 14(2): 69-82.

Turner LW., \& Reisinger, Y., (2001). Shopping satisfaction for domestic tourists. Journal of Retailing and Consumer Services. 8: 15-27.

Türofed (2013). Turizm Raporu. http://www.turofed.org.tr/PDF/DergiTr/Turizm_Raporurapor\%20turizm\%20turofed.pdf. 02.02.2015.

Um, S., \& Crompton, J. L. (1990). Attitude determinants in tourism destination choice. Annals of tourism research, 17(3), 432-448.

Üner, M. M., Sökmen, A. and Güller, D. (2007). "Her Şey Dahil Sisteminde Farklı Uygulamalar ve Antalya Ölçeğinde Bir Araştırma" Anatolia: Turizm Araştırmaları Dergisi, 18(1): 53-63.

Üngüren E. \& Cengiz F. (2009). "Her Şey Dahil Sisteminin Pazarlama Karması Unsurları Kapsamında Değerlendirilmesi”. 3. Ulusal Gastronomi Sempozyumu ve Sanatsal Etkinlikler, 17-18 Nisan, Antalya.

Uysal, M., \& Jurowski, C. (1994). Testing the push and pull factors. Annals of Tourism Research, 21(4), 844-846.

Wang, Y., Weaver, D. B., \& Kwek, A. (2016). Beyond the mass tourism stereotype: Power and empowerment in Chinese tour packages. Journal of Travel Research, 55(6), 724737.

Wiley, C.G.E., Shaw, S.M., \& Havitz, M.E. (2000). Men's and Women's Involvement in Sports: An Examination of the Gendered Aspects of Leisure Involvement. Leisure Sciences, 22, pp. 19-31.

Wong, C. K. S., \& Kwong, W. Y. Y. (2004). Outbound tourists' selection criteria for choosing all-inclusive package tours. Tourism management, 25(5), 581-592.

Wong, J. Y., \& Yeh, C. (2009). Tourist hesitation in destination decision making. Annals of Tourism Research, 36(1), 6-23.

Wong, S. \& Lau, E. (2001). Understanding the Behavior of Hong Kong Chinese Tourists on Group Tour Packages. Journal of Travel Research, 40(1): 57-67.

Wu, W. Y., Lu, H. Y., \& Lai, K. Y. (2014). The Influence of Service Performance in Group Package Tours on Tourist Loyalty toward Travel Agencies: An Application of Analytic Hierarchy Process. 企業管理學報, (101), 1-25.

Yayl1, A. \& Yayl1, I. (2012). Reasons of Tourists' Preferences of All-Inclusive System. Journal of Management Research. 4(1).143-162.

Yolal, M., Chi, C. G. Q., \& Pesämaa, O. (2017). Examine destination loyalty of first-time and repeat visitors at all-inclusive resorts. International Journal of Contemporary Hospitality Management, 29(7). https://doi.org/10.1108/IJCHM-06-2015-0293.

Yoon, Y., \& Uysal, M. (2005). An examination of the effects of motivation and satisfaction on destination loyalty: a structural model. Tourism Management, 26(1), 45-56.

Yuksel, A. (2004). Shopping experience evaluation: a case of domestic and international visitors. Tourism Management, Vol. 25, pp. 751-9.

Yürik, E. Ö. (2002). Her Şey Dahil Sistemi ve Sistemin Türk Turizm Sektörüne Etkileri, 2.Turizm Şurası Bildirileri, Cilt:1, Ankara: T.C. Turizm Bakanlığı. 
Zopiatis, A., Theocharous, A. L., \& Constanti, P. (2016). Adult vocational decision, career satisfaction and future intention: insights from the hospitality industry. International Journal of Contemporary Hospitality Management, 28(12). pp. 2696-2720. 
Table 5. Satisfaction Level of Respondents with Service Quality of All Inclusive System ( $\mathrm{n}=383$ )

\begin{tabular}{|c|c|c|c|c|c|c|c|c|c|c|c|c|}
\hline \multirow[t]{2}{*}{ Statements } & \multicolumn{2}{|c|}{ Strongly Disagree } & \multicolumn{2}{|c|}{ Agree } & \multicolumn{2}{|c|}{ Natural } & \multicolumn{2}{|c|}{ Agree } & \multicolumn{2}{|c|}{ Strongly Agree } & \multirow[b]{2}{*}{ Mean } & \multirow[b]{2}{*}{ SD } \\
\hline & $\mathrm{N}$ & $\%$ & $\mathrm{~N}$ & $\%$ & $\mathrm{n}$ & $\%$ & $\mathrm{n}$ & $\%$ & $\mathrm{n}$ & $\%$ & & \\
\hline Customers can feel safe during their holiday & 14 & 3.8 & 30 & 8.2 & 62 & 17.0 & 103 & 28.3 & 156 & 42.7 & 3.98 & 1.129 \\
\hline Rooms are cleaned on a regular basis daily & 24 & 6,6 & 47 & 12,9 & 51 & 14.0 & 97 & 26.5 & 146 & 40.0 & 3.81 & 1.270 \\
\hline Services and products are provided a in hygienic and healthy way & 16 & 4.5 & 47 & 13.2 & 75 & 21.1 & 115 & 32.3 & 103 & 28.9 & 3.68 & 1.155 \\
\hline Timely and fast customer service & 23 & 6.4 & 49 & 13.7 & 78 & 21.8 & 100 & 27.9 & 108 & 30.2 & 3.62 & 1.226 \\
\hline Provided correct and timely service at the first time & 19 & 5.4 & 54 & 15.3 & 80 & 22.6 & 110 & 31.0 & 91 & 25.7 & 3.57 & 1.179 \\
\hline Check-in and check-out procedures & 26 & 7.4 & 55 & 15.6 & 75 & 21.3 & 94 & 26.7 & 102 & 29.0 & 3.54 & 1.260 \\
\hline Customer comforts are kept in the forefront & 27 & 7.6 & 58 & 16.3 & 82 & 23.1 & 101 & 28.5 & 87 & 24.5 & 3.46 & 1.235 \\
\hline Air conditioning & 40 & 11.1 & 54 & 15.0 & 72 & 20.0 & 93 & 25.8 & 101 & 28.1 & 3.45 & 1.334 \\
\hline The avability, diversity and the capacity of the place that activities offered & 45 & 12.9 & 48 & 13.8 & 69 & 19.8 & 76 & 21.8 & 110 & 31.7 & 3.45 & 1.392 \\
\hline A possible defect in service was resolved in quick manner & 28 & 8.1 & 56 & 16.1 & 87 & 25.1 & 86 & 24.8 & 90 & 25.9 & 3.44 & 1.256 \\
\hline Customer are informed about the kind and content of services & 47 & 13.5 & 67 & 19.3 & 86 & 24.7 & 78 & 22.4 & 70 & 20.1 & 3.16 & 1.319 \\
\hline Overall satisfaction with service quality & & & & & & & & & & & 3.57 & 0.962 \\
\hline
\end{tabular}


Table 6 The effect of Iranian tourists' demographic characteristics on satisfaction of each dimension of behavioural intention

\begin{tabular}{|c|c|c|c|c|c|c|c|c|c|c|c|}
\hline \multicolumn{6}{|c|}{ Satisfaction from service quality of all-inclusive system } & \multicolumn{6}{|c|}{ Satisfaction for value for money for all-inclusive system } \\
\hline \multirow{3}{*}{$\begin{array}{c}\text { Demographic Characteristics } \\
\text { Gender } \\
\text { Male }\end{array}$} & $\mathrm{N}$ & Mean & SD & $\mathrm{T}$ & $\mathrm{p}$ & \multirow{3}{*}{$\begin{array}{c}\text { Demographic characteristics } \\
\text { Gender } \\
\text { Male }\end{array}$} & \multirow{3}{*}{$\begin{array}{c}\mathrm{N} \\
209\end{array}$} & \multirow{3}{*}{$\begin{array}{l}\text { Mean } \\
3.22\end{array}$} & \multirow{3}{*}{$\begin{array}{c}\text { SD } \\
0.952\end{array}$} & \multirow{3}{*}{$\begin{array}{c}\mathrm{t} \\
-2.945\end{array}$} & $\mathrm{P}$ \\
\hline & & & & & & & & & & & \\
\hline & 208 & 3.43 & 0.968 & -3.196 & 0.002 & & & & & & 0.003 \\
\hline Female & 169 & 3.74 & 0.927 & & & Female & 170 & 3.52 & 0.983 & & \\
\hline Age & $\mathrm{N}$ & Mean & $\mathrm{SD}$ & $\mathrm{F}$ & $\mathrm{p}$ & Age & $\mathrm{N}$ & Mean & SD & $\mathrm{F}$ & $\mathrm{p}$ \\
\hline Younger than 20 & 44 & 3.69 & 0.983 & 4.446 & 0.002 & Younger than 20 & 45 & 3.65 & 0.801 & 5.723 & 0.000 \\
\hline 20 to 29 & 114 & 3.37 & 0.790 & & & 20 to 29 & 114 & 3.12 & 0.958 & & \\
\hline 30 to 39 & 98 & 3.42 & 1.096 & & & 30 to 39 & 98 & 3.19 & 1.081 & & \\
\hline 40 to 49 & 62 & 3.76 & 0.952 & & & 40 to 49 & 63 & 3.48 & 0.781 & & \\
\hline 50 or older & 57 & 3.90 & 0.911 & & & 50 or older & 57 & 3.70 & 0.982 & & \\
\hline
\end{tabular}

